Author: LA Tong

PROTECTING TRADITIONAL KNOWLEDGE - DOES SECRECY OFFER A SOLUTION?

ISSN 1727-3781

2010 VOLUME 13 No 4 


\section{PROTECTING TRADITIONAL KNOWLEDGE - DOES SECRECY OFFER A SOLUTION?}

\section{L-A Tong}

\section{General}

The search for new information that will lead to advances in science and technology, combined with the economic imperative to acquire exclusive rights over commercially profitable knowledge has threatened the supply and conservation of natural resources, and impacted on the cultural lives of many traditional communities which hold valuable traditional knowledge. ${ }^{1}$ This ongoing quest in the name of progress places traditional communities under increasing pressure to respond to the threat that the irresponsible harvesting of natural resources poses to their livelihood. To be added to this this is the misappropriation of traditional knowledge by persons outside of the traditional community through the use of the intellectual property system with its focus on the privatisation of knowledge. ${ }^{2}$ The intellectual property

Lee-Ann Tong. LLM (London) LLM (Turin). Lecturer, Department of Private Law, University of Cape Town. Lee-ann.Tong@uct.ac.za

Note on terminology: the search for a definition of "traditional knowledge" (TK) is well documented and will not be dealt with in this paper. The approach adopted by the World Intellectual Property Organisation (WIPO) is useful and relevant in this context. The WIPO uses the term "traditional knowledge" as a working term to refer to "tradition-based literary, artistic or scientific works; performances; inventions; scientific discoveries; designs; marks, names and symbols; undisclosed information; and all other tradition-based innovations and creations resulting from intellectual activity in the industrial, scientific, literary or artistic fields. 'Traditionbased' refers to knowledge systems, creations, innovations and cultural expressions which: have generally been transmitted from generation to generation; are generally regarded as pertaining to a particular people or its territory; and, are constantly evolving in response to a changing environment .... Excluded from this description of TK would be items not resulting from intellectual activity in the industrial, scientific, literary or artistic fields, such as human remains, languages in general, and other similar elements of 'heritage' in the broad sense (WIPO Intellectual Property Needs 25)". In addition, in this paper it is understood that indigenous knowledge would be "the traditional knowledge of indigenous peoples" and that [i]ndigenous knowledge is therefore part of the traditional knowledge category, but traditional knowledge is not necessarily indigenous. That is to say, indigenous knowledge is traditional knowledge, but not all traditional knowledge is indigenous." WIPO Intellectual Property Needs 23. Furthermore, the references to the "holder(s)" of traditional knowledge also follow the WIPO approach and refer to "all persons who create, originate, develop and practice traditional knowledge in a traditional setting and context (WIPO Intellectual Property Needs 26)". Communities are included in this understanding of "holder".

2 Traditional knowledge may take many forms, from extraction methods, knowledge of plant material properties, agricultural methods, and healing techniques, to rituals, folklore, dance, and 
system has allowed for intellectual property rights to be obtained over inventions and creations based on existing traditional knowledge. Patents have been based on the wound-healing powers of turmeric ${ }^{3}$ and the appetite-suppressant properties of the Hoodia plant, ${ }^{4}$ and sacred chants and traditional music have been used by western artists to create musical works for which they claim copyright ${ }^{5}$ Although intellectual property rights over intellectual creations derived from traditional knowledge may be acquired legally, the failure to recognise the contributions of the traditional knowledge holders and to share the benefits the economic gains derived from intellectual property rights have made the relationship between traditional knowledge and the intellectual property system a strained one. ${ }^{6}$ These and other concerns have led to traditional knowledge receiving increasing attention in international forums such as the World Intellectual Property Organisation (WIPO) and the World Trade Organisation (WTO). One issue among the many debated in connection with the recognition and protection of traditional knowledge is whether or not it is possible for traditional knowledge holders to use the existing intellectual property system to their advantage. $^{7}$ In this regard, while much has been written about the shortcomings in the traditional knowledge context of intellectual property rights like copyright and patents, little attention is usually paid to the use of trade secrecy, ${ }^{8}$ even though it is recognised as a form of protection for industrial property and is widely used in western economies to ensure that confidential technical and commercial information is not disclosed to trade rivals. ${ }^{9}$

music, all of which may provide the basis for intellectual property rights under the intellectual property system.

Dutfield "Protecting and Revitalising Traditional Ecological Knowledge" 103-122.

Wynberg 2004 JWIP 851-876.

Gervais 2001 www.cra-adc.ca; Mcleod Owning Culture 46-50.

Gervais 2001 www.cra-adc.ca 3.

Gervais 2001 www.cra-adc.ca 6-7.

In this paper the term "secret information" will be used to refer to information that the holder wishes should remain undisclosed. The term is broad enough to include other terms like "trade secrets," "confidential information" and "undisclosed information," all of which may have particular characteristics that make them less inclusive than "secret information". This is important because there are different types of information that a traditional knowledge holder may want to keep secret, some of which, for example sacred knowledge, would not fit into the general understanding, for example, of trade secrets as business information of economic value in trade and industry. The WIPO Model Provisions on Protection Against Unfair Competition (Model Provisions 1996) also suggests the use of the term "secret information (A 6 and para 6.16)."

9 Even outside of the traditional knowledge context, trade secrecy attracts little real discussion compared with other forms of intellectual property protection. See Landes and Posner Economic Structure 354. 
There is little doubt that the use of secrecy to protect traditional knowledge is an attractive option. ${ }^{10}$ Conceptually, secrecy provides a form of protection that may either already be part of an existing custom, for example where certain sacred rites or practices are known only to certain members of the community; or it may be an external protective mechanism in response to the threat of misappropriation by nonmembers. In the latter case secrecy may be used to stop the unauthorised flow of information from the traditional knowledge holders to outsiders either because the traditional knowledge holders wish to retain a measure of control over the way in which the secret information is used or commercialised, perhaps in anticipation of being able to negotiate with third parties, or simply to prevent others accessing it.

An advantage in using secrecy is that it can, at least in theory, be used to protect any type of traditional knowledge, from products like chemical compounds or formulae, to ways of doing things, like therapeutic techniques or processes for creating medicinal compounds. ${ }^{11}$ The information need not meet criteria as to type and there are no substantive hurdles like the requirement of originality or novelty, which are required for copyright and patent protection respectively. ${ }^{12}$ The lack of a registration procedure with its associated legal complexities and costs also contributes to making secrecy an attractive option for traditional knowledge holders, and unlike most intellectual property rights which are of limited duration, traditional knowledge protected by secrecy will remain protected for as long as it is not disclosed.

Thus, at first blush, secrecy provides traditional knowledge holders with a costeffective, formality-free way of preventing the misappropriation of traditional knowledge. All that is required is that no-one finds out. However, as easy as it may be to decide to use secrecy, so too is it easy to lose secrecy. Once there has been disclosure, the value of the information is lost and cannot be regained, regardless of whether this has been through the unauthorised disclosure of the information, or

10 See for example Dutfield "Protecting Traditional Knowledge" 81-82; Dutfield 2001 Case W Res J Int'I L 258; UNCTAD-ICTSD Resource Book on TRIPS 538.

11 However, secrecy lends itself more readily to the concealment of certain types of information. Not all traditional knowledge can be kept secret, and for some, doing so may render the knowledge inert, for example, textile patterns and other knowledge the use of which entails disclosure. Arguably, secrets that relate to methods are better suited to secrecy because the information will enter the public domain much quicker if it is in product form. Once the knowledge has been integrated into product form, it may be more susceptible to reverse engineering. 
through independent development such as reverse engineering. Where secrecy has been compromised or threatened, the legal recourse that the holder of secret traditional knowledge may rely on will depend on the nature of the information as well as the circumstances in which the remedy is sought. Relief for the loss of secrecy will usually be restricted to claims for compensation or damages, or for an interdict to prevent disclosure. While actions based on the disclosure of secret information are usually grounded in unlawful competition, contract, fiduciary duties, statute, criminal sanctions, breach of confidence actions, or privacy; depending on the particular jurisdiction, not all of these may be relevant to traditional knowledge. This article will consider only two forms of legal recourse to protect secret traditional knowledge, namely unlawful competition and contract.

\section{Preliminary issues}

The determination of whether or not secrecy can in law provide the basis for the protection of traditional knowledge, can be made only within the context of the other issues associated with the protection of traditional knowledge. These issues underlie any attempt to reconcile intellectual property rights with traditional knowledge, and include defining or delineating the ambit of what constitutes traditional knowledge and identifying who the rightful holders of such traditional knowledge are.

For the purpose of this paper, which is to review the extent to which unlawful competition and contract law potentially provide legal remedies to protect traditional knowledge, it must be remembered that all traditional knowledge can clearly not be said to be secret. Whether or not the knowledge that is sought to be "protected" as a trade secret ${ }^{13}$ is in fact, secret, and is not part of the public domain, is a question of fact, to be determined in relation to the particular subject matter sought to be protected. ${ }^{14}$ Thus secrecy as a legal option for traditional knowledge holders will be limited to only those instances where the specific knowledge meets the legal requirements for the proposed remedy.

\footnotetext{
13 Traditional knowledge "secrets" could, for example, be formulae for medicines, recipes, knowhow, and the like.

14 Elvin-Lewis 2007 Afr J Trad CAM 443-468.
} 
A second issue that underlies all of the legal remedies is the determination of who has the locus standi to bring the action. Once an individual or a traditional community makes a legal claim to traditional knowledge or to stop the use of traditional knowledge, then the issue of ownership arises. It is obviously not easy to identify a single creator or source of traditional knowledge. The approach to identifying the legal holder of the traditional knowledge, whether that is an individual or a community, will depend on the measures, if any, that the particular jurisdiction has put in place.

\section{Protection of secret traditional knowledge under the Agreement on Trade-Related Aspects of Intellectual Property Rights}

Although the misappropriation of trade secrets or confidential information has for a long time been actionable in many domestic jurisdictions, ${ }^{15}$ the Agreement on Trade Related Aspects of Intellectual Property Rights ${ }^{16}$ (the TRIPS Agreement) is the first international intellectual property instrument to specifically recognise secret information or "undisclosed information" as being protectable intellectual property. ${ }^{17}$ This is done through Article 39 of the TRIPS Agreement, which makes provision for the protection of undisclosed information under the ambit of unfair competition. ${ }^{18}$

Article 39 of the TRIPS Agreement provides that:

1 In the course of ensuring effective protection against unfair competition as provided in Article 10bis of the Paris Convention

15 Legal action to protect against trade secret misappropriation has taken many forms, for example through statutes such as the United States of America's Uniform Trade Secrets Act 1985, and common law, such as the delict of unlawful competition in South Africa.

16 Agreement on Trade-Related Aspects of Intellectual Property Rights 1994 constitutes Annex 1C of the Marrakesh Agreement Establishing the World Trade Organisation and entered into force on 1 January 1995.

17 A 1.2 of the TRIPS Agreement provides that "the term 'Intellectual Property' refers to all categories of intellectual property that are the subject of Sections 1 through 7 of Part II". S 7 deals with the protection of "undisclosed information". The TRIPS Agreement does not use the terms "trade secrets" or "confidential information" although these terms are commonly used in legal discourse on the protection of secret information. A reason for this may be that there is no agreement as to what would constitute a "trade secret" or "confidential information" and that the term "undisclosed information" is more neutral. See UNCTAD-ICTSD Resource Book on TRIPS 520-521.

18 Although the Paris Convention for the Protection of Industrial Property (1967) provides for protection against unfair competition in A 10 bis thereof, it does not refer to secret or undisclosed information specifically. 
(1967), Members shall protect undisclosed information in accordance with paragraph 2 and data submitted to governments or governmental agencies in accordance with paragraph 3.

$2 \quad$ Natural and legal persons shall have the possibility of preventing information lawfully within their control from being disclosed to, acquired by, or used by others without their consent in a manner contrary to honest commercial practices so long as such information:

(a) is secret in the sense that it is not, as a body or in the precise configuration and assembly of its components, generally known among or readily accessible to persons within the circles that normally deal with the kind of information in question;

(b) has commercial value because it is secret; and

(c) has been subject to reasonable steps under the circumstances, by the person lawfully in control of the information, to keep it secret.

The TRIPS Agreement requires that Members of the WTO incorporate minimum levels of intellectual property protection into their domestic laws. However, Members may choose to impose more stringent measures and may do this through whatever means they prefer. ${ }^{19}$ It follows that the provisions relating to unfair competition in Article 39 may be expanded upon and interpreted in ways that provide broader protection to the holders of undisclosed information. As will be seen from the ensuing discussion, the use of unfair competition rules to protect undisclosed information may not offer much benefit to traditional knowledge holders unless domestic unfair competition models provide for the specific challenges that accompany a minimum application of Article 39.

Unfair competition rules generally do not provide the holder of secret information with an exclusive right in the information itself but make it possible to prevent acts of disclosure, acquisition and use without consent and contrary to honest business practice within a competition environment. ${ }^{20}$ How one determines if the actions have been less than honest will depend on the particular jurisdiction's approach, although it will usually be relative to the community at the time as to what will constitute a

19 A 1.1 provides that "[m]embers shall give effect to the provisions of this Agreement. Members may, but shall not be obliged to, implement in their law more extensive protection than is required by this Agreement, provided that such protection does not contravene the provisions of this Agreement. Members shall be free to determine the appropriate method of implementing the provision of this Agreement within their own legal system and practice."

20 See further UNCTAD-ICTSD Resource Book on TRIPS 527. 
condemnable practice. ${ }^{21}$ Consequently, a key limitation in the application of Article 39 of the TRIPS Agreement to traditional secret information is that it presupposes a competitive environment, and thus also a commercial context. If this is interpreted strictly it may result in the reduced relevance of unfair competition for traditional knowledge holders who do not use their secret information in a commercial context and who would in most cases not be direct trade rivals of the person responsible for the misappropriation. An example of this would be where a multinational pharmaceutical company acquires undisclosed traditional knowledge about the appetite-suppressant properties of a particular plant and uses the information in the development and marketing of a lifestyle drug to curb obesity. This would not be a relationship of trade rivalry, in the usual sense of the words, between the traditional knowledge holder and the company.

The relevance of Article 39 would be increased by an implementation into domestic law that tended toward the WIPO Model Provisions 1996 which suggest that an act of direct competition is not necessary because even where:

an act is not directed against a competitor of the person who has committed the act, it may nevertheless influence competition in the market by increasing the competitiveness of that person in relation to his competitors. ${ }^{22}$

This approach is borne out also by the WIPO definition of unfair competition as:

any act that a competitor or another market participant undertakes with the intention of directly exploiting another person's industry or commercial achievement for his own business purposes without substantially departing from the original of his achievement. ${ }^{23}$

21 Footnote 10 of the TRIPS Agreement clarifies A 39.2. with the note that that for the purpose of the provision "'a manner contrary to honest commercial practices' shall mean at least practices such as breach of contract, breach of confidence and inducement to breach, and includes the acquisition of undisclosed information by third parties who knew, or were grossly negligent in failing to know, that such practices were involved in the acquisition". In South Africa this would be found in the unlawfulness or wrongfulness component of a delict and would be tested against the boni mores of society. See also UNCTAD-ICTSD Resource Book on TRIPS 528-529.

22 Model Provisions 1996 para 1.06.

23 UNCTAD-ICTSD Resource Book on TRIPS 521, see footnote 1013 therein. 
Not all undisclosed information would be protectable under unfair competition rules. Article 39.2 is limited to information that meets three requirements. The first requirement is that the information must be:

secret in the sense that it is not, as a body or in the precise configuration and assembly of its components, generally known among or readily accessible to persons within the circles that normally deal with the kind of information in question. ${ }^{24}$

The provision does not make absolute secrecy a requirement. Instead the standard is found in the less strict obligation that the information is "generally not known" or "readily accessible" to "persons within the circles that normally deal with the kind of information in question". More than one person may be privy to the information without compromising secrecy. This approach is favourable for the protection of secret traditional knowledge, especially where the knowledge is held by a community. However, inherent in this formulation is that information that is generally known among or readily accessible to persons within circles that deal with such information will not meet the secrecy requirement. This raises the issue of the identification of such persons with access to the information, particularly where the traditional knowledge is known to the whole community, to specific groups within the community, or to persons outside of the community. ${ }^{25}$ It may be that information must be kept not only from non-members who are in a competitive relationship with the traditional knowledge holder, but also from other members of the community who are not allowed access to the information. For example within a traditional community, a secret healing method may be handed down from generation to generation of traditional healers and kept secret from other members of the community.

A 39.2(a) TRIPS Agreement.

For example, would a researcher conducting research on the healing properties of medicinal plants used by the traditional community, be considered as part of the circle? Furthermore, the question that one may then ask is whether or not there are any limits on the number of persons who are privy to the secret by considering, for example the size of the community or if it is restricted to a particular geographical area. It is arguable that the larger the community and the fewer people proportionately who have access to the information, the more likely it is that the information may be secret. 
The second requirement is that the information must have commercial value because of its secrecy. ${ }^{26}$ The value of undisclosed information is derived from the fact that those who are privy to the secret have lead time in the market over competitors who have yet to discover the information. If everyone who is in competition has access to the information then there is no commercial value to the holder. However, if the information has commercial value because of its secrecy, then arguably such commercial value must be to the holders. While traditional knowledge that is sought by outsiders in commercial enterprises inevitably has commercial value, the question that arises is whether or not a traditional community that is not using the information commercially can make this claim. The TRIPS Agreement also seems to provide that the information must have actual value. However, because Member states may provide stronger protection, it is possible to protect information that has potential commercial value. Thus, a traditional community, even if not using traditional knowledge commercially, will be able to meet this criterion by claiming that the information could be used commercially. However, if the information has value only to the holders because of its spiritual or religious aspects it may be difficult to meet this requirement.

The third requirement is that the person under who has lawful control of the information, must have taken steps to maintain the secret. ${ }^{27}$ The wording of the section seems to require positive action on the part of the holder. While proof of encryption, security guards, and access control may be evidence of such measures in western industrialised economies, it is more difficult to provide proof of such steps in a traditional community. It is therefore less clear what would suffice as protection of the secrecy oftraditional knowledge that may be held communally, particularly where there may be little proof other than an obligation to maintain secrecy. Even if we adopted the WIPO Model Provisions 1996 on the equivalent of this section, none of the suggested factors speak to the concerns of traditional knowledge holders. Article 6(3)(iii) of the WIPO Model provides that:

[i]n determining whether reasonable steps have been taken to keep the information secret, account should be taken of the amount of effort and money spent by the rightful holder on developing the secret 
information, the value of that information to him and to his competitors, the extent of the measures taken by the rightful holder to keep the information secret and the ease or difficulty with which it could be lawfully acquired by others. Moreover, the secret information has to be identifiable, for example in documents or through storage in a database. Although contractual obligations are not necessary, the rightful holder must have shown his intention to have the information treated as secret.

\section{$4 \quad$ The protection of secret traditional knowledge in South Africa}

South Africa has a reasonably comprehensive intellectual property rights system in place, primarily through statutory provisions such as the Copyright Act 98 of 1978, the Patents Act 57 of 1978, and the Trade Marks Act 194 of 1993. The protection of secret information from misappropriation is really actionable under common law only, primarily in the law of delict ${ }^{28}$ or through the enforcement of contractual agreements which impose obligations of confidence. ${ }^{29}$ While the existing intellectual property laws do not deal with the protection of traditional knowledge in any great depth, ${ }^{30}$ there is currently underway a legislative process to amend the intellectual property legislation to provide for traditional knowledge. ${ }^{31}$ In the policy document that accompanied the proposed new legislation, it is noted that while trade secret protection, being perpetual, may "be the best method of protecting traditional knowledge under most circumstances"..."traditional knowledge holders should be

28 The disclosure of secret traditional information could possibly form the basis for an action relating to the right to privacy, in which case the actio iniuriarum would be the appropriate action. See Financial Mail (Pty) Ltd v Sage Holdings Ltd 1993 (2) SA 451 (A). However, the right to privacy will not be explored in this paper, and the focus will be on Aquilian liability.

29 Unlike some common law systems, such as those of, Botswana and Australia, South African law does not have an action outside of contract for breach of confidence which would allow an equitable remedy where a person who has received information in confidence, takes unfair advantage of that confidence. See Dun \& Bradstreet (Pty) Ltd v SA Merchants Combined Credit Bureau (Cape) (Pty) Ltd 19681 SA 209 (C); Atlas Organic Fertilizers (Pty) Ltd v Pikkewyn Ghwano (Pty) Ltd 19812 SA 173 (T); Pistorius and Visser 1993 SA Merc LJ 330-345. See further Kiggundu "Intellectual Property Law" 29; Aplin 2007 IPQ 19-59. A well-known example of the use of the breach of confidence action used by traditional knowledge holders is the Australian case of Foster v Mountford 197629 FLR (see Posey and Dutfield Beyond Intellectual Property 47).

30 The Patents Act was amended by the Patents Amendment Act 20 of 2005 to require an applicant for a patent to furnish information relating to any role played by an indigenous biological resource, a genetic resource or traditional knowledge in an invention.

31 GN 552 in GG 31026 of 5 May 2008 (Policy Framework for the Protection of Indigenous Traditional Knowledge through the Intellectual Property System and the Intellectual Property Laws Amendment Bill). 
encouraged to use trade secret protection with caution". ${ }^{32}$ However, the proposed amendments do not deal with trade secrets at all.

\subsection{Using the Action legis Aquiliae to protect secret traditional knowledge in South Africa}

South African common law provides legal recourse in the form of Aquilian liability for patrimonial loss that has been caused culpably and unlawfully. Given that there is arguably no limit to the type of claims for patrimonial loss that may be brought under this head, and provided that the requirements are fulfilled, ${ }^{33}$ it could be possible to use the action to claim compensation where secret traditional knowledge has been wrongfully misappropriated. ${ }^{34}$ Most delictual matters for the wrongful misappropriation of secret information that have been before the courts have been decided within the context of unlawful competition. ${ }^{35}$ The South African courts have long recognised unlawful competition as a basis for invoking Aquilian liability, the wrongfulness being manifested in the infringement of the plaintiff's right to attract custom. ${ }^{36}$ Although there is no closed list of the types of behaviour that would give rise to an unlawful competition action, certain forms have been recognised, including the right not to have ones' confidential information misappropriated. ${ }^{37}$ The relief at the plaintiff's disposal will be either in the form of a claim for damages under the Actio Legis Aquilia or for an interdict.

32 Gen Not 552 in GG 31026 of 5 May 200819.

33 The usual requirements for a delict are an act or conduct, wrongfulness, fault, causation, and damage; Neethling Unlawful Competition 69, 73, 80.

34 Financial Mail v Sage Holdings 19932 SA 451 (A); Harchris Heat Treatment (Pty) Ltd v Iscor 19831 SA $548(\mathrm{~T})$.

35 Unlawful competition provides a remedy for the infringement of the right to attract custom and is not a property right. However, it has been argued that it is possible to claim a right to a trade secret on the basis that a trade secret is an incorporeal product of the human mind which constitutes immaterial property and as such may be the object of a subjective property right. If this is accepted, then an infringement of such a right, even though not within an unlawful competition context, will also give rise to a delictual action. See Domanski 1993 THRHR 432, 442-443; Knobel 2000 Acta Juridica 196, 205-206; Knobel 2001 THRHR 583; Neethling Unlawful Competition 76-77, 213-214.

36 Mathew v Young 1922 AD 492, Patz v Greene \& Co 1907 TS 427; Atlas Organic Fertilizers (Pty) Ltd v Pikkewyn Ghwano; Geary and Son (Pty) Ltd v Gove 19641 SA 434 (A); Neethling Unlawful Competition 74-75, 79; Webster and Morley South African Law of Trade Marks 15-5-15-6.

37 Dun \& Bradstreet (Pty) Ltd v SA Merchants Combined Credit Bureau (Cape) (Pty) Ltd 19681 SA 209 (C) 221; Atlas Organic Fertilizers (Pty) Ltd v Pikkewyn Ghwano (Pty) Ltd \& Others 19812 SA 173 (T); Neethling Unlawful Competition 219-223. 
Generally, a number of requirements must be met to bring such an action. A first requirement is that that the person bringing the action has a legal interest in the matter. Since the basis for the action is unlawful competition which affects a competitor's goodwill and not a proprietary right, not only the "owner" but any person with a legal interest (for example a licensee) may launch proceedings. ${ }^{38}$ This may help avert potential concerns about which members of a traditional community may bring an action. The second requirement for the delict is that the defendant performed an improper act in respect of the secret. Whether or not the secret was dealt with in a manner that is unlawful or wrongful would be determined according to the boni mores of the societal yardstick. ${ }^{39}$ It is also necessary that there should have been fault either in the form of negligence or intention, and that the plaintiff suffered damages. These last two requirements would not be necessary if the relief sought were an interdict to prevent disclosure of the information as opposed to damages. If damages are claimed for patrimonial loss then the traditional community will need to quantify their "damage" as a result of the loss of secrecy. If the community is not engaged in trade or if the secret information is of a type that cannot be said to have an economic value (for example, because it is of sacred value to the community) then the Aquilian action would fail. A final requirement, and one which may prove the most burdensome for traditional knowledge holders who wish to use unlawful competition as the basis for legal action is that it must be proved that the information is worthy of protection. This is usually taken to mean that the information must be a "trade secret".

Irrespective of whether the relief is sought under the head of unlawful competition specifically or the actio Legis Aquilia generally, the traditional knowledge holders will have to show that the information is worthy of protection, since information per se is not protectable. Although the terms "trade secret" and "confidential information" are frequently used by the courts to refer to secret information, there are no legal definitions for either. The courts have, however, referred to certain criteria (which happen to be very similar to that set out in Article 39(2)(a) to (c) of the TRIPS

Domanski 1993 THRHR 434.

For more on the unlawfulness requirement, see Webster and Morley South African Law of Trade Marks 15-6-15-14. 
Agreement) that may be relevant in determining whether the information is protectable or not.

Firstly, the information for which protection is sought must be confidential or secret. It has been said that secrecy implies that the information must be known only to a closed circle and must have been treated as confidential. ${ }^{40}$ It must not be public property or knowledge. ${ }^{41}$ There must have been an attempt on the part of the holder to keep the information secret. ${ }^{42}$ As with Article 39.2(a) of the TRIPS Agreement, absolute secrecy is not a requisite. ${ }^{43}$ While the concerns raised in relation to that provision apply equally well here, it is submitted that in many cases the traditional knowledge holders will be able to meet this standard.

Secondly, the information must, objectively, be of economic value. ${ }^{44}$ This may be difficult for traditional knowledge holders to prove, not least because the information may not be of the type that can be valued economically, possibly because it holds religious or sacred value to the holders. However, a flexible approach that accepts that a secret will be commercially valuable if it has potential although unrealised value would enable the traditional knowledge holders to meet this requirement, even if the information is not being used commercially. A related question is if the economic value must be to the traditional community or to an outsider. It is arguable that it does not really matter which approach is adopted and that the determination of whetheror not the information is of economic value may be in relation to whichever party. ${ }^{45}$

$40 \quad$ Atlas Organic Fertilizers (Pty) Ltd v Pikkewyn Ghwano (Pty) Ltd 19812 SA 173 (T) 194; Easyfind International (SA) (Pty) Ltd v Instaplan Holdings 1983 3 SA 917 (W) 929. Knobel 2000 Acta Juridica 196-197 says that the owner must have the will to keep the information secret; Pistorius and Visser 1993 SA Merc LJ 339.

41 Knobel 2001 THRHR 584-585; Neethling Unlawful Competition 215-216.

42 Knobel 2001 THRHR 586.

43 Knobel 2001 THRHR 584-585.

44 Knobel 2000 Acta Juridica 196-197; Knobel 2001 THRHR 587; Neethling Unlawful Competition 216.

45 One view is that the information must be of economic value to the person seeking to protect it (Neethling Unlawful Competition 216; Canon KwaZulu-Natal (Pty) Ltd t/a Canon Office Automation $v$ Booth and Another 20053 SA $205(\mathrm{~N}))$. Others are of the view that it makes no difference (Knobel 2001 THRHR 587). 
Thirdly, it seems accepted that the information must relate to or be applied in trade and industry. ${ }^{46}$ Even though the traditional knowledge holders may not be using the information in trade or industry per se, it could be argued that the information that has been disclosed is being used for such purposes by the defendant party. It would seem that as long as the information could be used in industry or commerce, then it ought to meet this requirement. ${ }^{47}$

Fourthly, it has also been suggested that to be a trade secret, the information must have an existence separate from its owner. ${ }^{48}$ This may be particularly difficult to show, because the very nature of traditional knowledge is such that it is an integral part of the lives of those who practise it daily; and in some cases certain types of information, for example certain rituals, may be practiced only by some members of the group.

Over and above the difficulty involved in attempting to meet these specific requirements, there is the more general stumbling block posed for traditional knowledge holders claiming that that they are subject to unlawful competitionthat they have to show that this is taking place in a competitive context. Van Heerden and Neethling ${ }^{49}$ note in this regard that "there can be no question of unlawful competition without competition". However, they do suggest that potential competition might suffice as opposed to actual competition, although the "potential competition" must be understood "not in the sense that everyone is free to enter the market and therefore potential competitors" but rather "on a balance of probabilities, the particular business is about to enter the market or will imminently become a competitor". ${ }^{50}$ Although a requirement of potential rather than actual competition favours traditional knowledge holders who would probably not be engaged in commercial activity with their traditional knowledge in the ordinary course of events, this formulation will reduce the relevance even of "potential competition" to the traditional knowledge holders.

\footnotetext{
Neethling Unlawful Competition 215.

Knobel 2000 Acta Juridica 196-197; Knobel 2001 THRHR 584.

Knobel 2000 Acta Juridica 196-197; Knobel 2001 THRHR 588.

Neethling Unlawful Competition 78 and particularly fn 9 therein.

Neethling Unlawful Competition 78.
} 


\subsection{Using contractual arrangements to protect secret traditional knowledge in South Africa}

Entering into a contract is generally considered as a flexible way in which traditional knowledge holders can regulate the use of traditional knowledge, and one with fewer legal requirements than using unlawful competition to protect secret information. However, a contractual arrangement that imposes an obligation of confidentiality on another party will usually occur only as part of an agreement to license traditional knowledge or provide access to it. The usual form of such "non-disclosure agreements" is that in exchange for access to secret knowledge, the traditional knowledge holders derive benefits, like royalty payments, along with the undertaking that the information will not be made public. ${ }^{51} \mathrm{~A}$ non-disclosure agreement would have to include a description of the traditional knowledge that is subject to confidentiality $^{52}$, the identification of the owners of the traditional knowledge, the restrictions on the use of the knowledge by the recipient, the nature and amount of compensation, and the duration of the agreement. In addition, the general principles of contract law would apply, depending on the particular jurisdiction.

However, confidentiality agreements may also provide that both parties are restricted in what they can do with the information identified in the contract, which could effectively stop the traditional knowledge holders from using the information for other purposes, such as negotiating with other parties. An advantage inherent in the use of acontract is that it is possible to provide that royalty payments and benefits continue to flow to the community even once secrecy is lost, provided the traditional community is not in breach.

However, there are various shortcomings to relying on contracts. A key issue is the inevitable loss of secrecy. Although it may be possible to enter into contractual arrangements as part of an agreement to commercialise the knowledge, the information will inevitably end up in the public domain, for example, medicinal

\footnotetext{
$51 \quad$ Posey and Dutfield Beyond Intellectual Property 88.

52 This would also imply an identification of knowledge that is outside the scope of the agreement, for example knowledge that is already in the possession of the recipient or which loses its secrecy through no breach of the agreement by the recipient.
} 
knowledge incorporated in a new product that is then marketed may be discovered through reverse engineering. ${ }^{53}$

A further concern is that a contract is enforceable only against the parties to the agreement and will not assist where a third party uses secret information without permission. Privity of contract may also be an issue in terms of binding successors when a contractant dies. On a practical level there is a very basic concern when using contract that traditional knowledge holders may be at a disadvantage either because of a lack of capacity and experience to negotiate favourable terms with corporate organisations like multinational pharmaceutical companies and biotechnology companies. ${ }^{54}$ This compounds a further problem, namely the inherent difficulties in determining the value of the secret information, since it may not be possible to determine at the time of contracting if it is possible to transform the information or raw material into a profit-generating source. The traditional knowledge holders may not be in a position to know what a fair asking price would be.

\section{$5 \quad$ The shortcomings of secrecy}

It is clear that there are inherent difficulties in finding a legal remedy for traditional knowledge holders who wish to rely on secrecy to protect traditional knowledge.

In South Africa it is currently arguable that the most relevant legal actions possible are delict and contract, neither of which is of much use once the information has been disclosed; and both are costly and time-consuming to enforce. Furthermore, neither action can assist where secrecy is lost through independent research or without blameworthiness; and to the extent that they do provide relief, the relief is for the most part confined within South Africa. It is suggested that the use of secrecy alone as a means to protect the interests of traditional knowledge holders does not, in the South African context, provide sufficient relief. However, given that it is highly unlikely that there will be any legislative reform of this area generally, there is even less hope that there will be an intervention to deal with secret traditional knowledge. To the extent that it is possible, traditional knowledge holders are best advised to

\footnotetext{
53 More specifically, secrecy will not be of great use when a traditional medicine is developed commercially, since, for public health reasons, authorities will require disclosure of the medicine's composition as a condition for marketing authorization. In this regard consider the provisions of $A$ 39.3 of the TRIPS agreement. See Dinca 2005 JWIP 517-564; Meitinger 2005 JWIP 123-140.

54 Feris 2004 African Human Rights Journal 249.
} 
consider the downside of relying only on secrecy to protect valuable traditional knowledge and should rather consider it a supplementary, not a primary source of protection. 


\section{Bibliography}

Aplin 2007 IPQ

Aplin T "The development of the action for breach of confidence in a post-HRA era" 2007 IPQ 19-59

Dinca 2005 JWIP

Dinca R "The 'Bermuda Triangle' of Pharmaceutical Law - Is Data Protection a Lost Ship?" 2005 JWIP 517-564

Domanski 1993 THRHR

Domanski A "Trade secrets through the cases: a study of the basis and scope of protection (continued)" 1993 THRHR 430-449

Dutfield "Protecting and Revitalising Traditional Ecological Knowledge"

Dutfield G "Protecting and Revitalising Traditional Ecological Knowledge: Intellectual Property Rights and Community Knowledge Databases in India" in Blakeney M Intellectual Property Aspects of Ethnobiology (Sweet and Maxwell London 1999) 103-122

Dutfield 2001 Case W Res J Int'l L

Dutfield G "TRIPS-Related Aspects of Traditional Knowledge" 2001 Case W Res $J$ Int'I L 233-275

Dutfield "Protecting Traditional Knowledge"

Dutfield G "Protecting Traditional Knowledge and Folklore" in Grosheide W and Brinkhoj J (eds) Intellectual Property Law Articles on Cultural Expressions and Indigenous Knowledge (Intersentia Antwerp 2002) 63-96

Elvin-Lewis 2007 Afr J Trad CAM

Elvin-Lewis $M$ "Evolving Concepts Related to Achieving Benefit Sharing for Custodians of Traditional Knowledge" 2007 Afr J Trad CAM 443-468 
Feris 2004 African Human Rights Journal

Feris $L$ "Protecting indigenous knowledge in Africa: considering African approaches" 2004 African Human Rights Journal 242-255

Kiggundu "Intellectual Property Law"

Kiggundu $\mathrm{J}$ "Intellectual Property Law and the Protection of Indigenous Knowledge" in Mazonde I and Thomas P (eds) Indigenous Knowledge Systems and Intellectual Property in the Twenty-first Century: Perspectives from Southern Africa (CODESRIA Senegal 2007) 26-47

Knobel 2000 Acta Juridica

Knobel $\mathrm{J}$ "Wrongfulness of trade secret misappropriation and trade secrets as objects of subjective rights" 2000 Acta Juridica 196-212

Knobel 2001 THRHR

Knobel J "Trade secrets and the doctrine of subjective rights" 2001 THRHR 572595

Landes and Posner Economic Structure

Landes WA and Posner RA The Economic Structure of Intellectual Property Law (Harvard University Press Cambridge 2003)

Mcleod Owning Culture

Mcleod K Owning Culture (Peter Lang New York 2001)

Meitinger 2005 JWIP

Meitinger I "Implementation of Test Data Protection According to Article 39.3 TRIPS - The Search for a Fair Interpretation of the Term 'Unfair Commercial Use'" 2005 JWIP 123-140

Neethling Unlawful Competition

Neethling J Van Heerden-Neethling Unlawful Competition $2^{\text {nd }}$ ed (LexisNexis Durban 2008) 
Pistorius and Visser 1993 SA Merc LJ

Pistorius $\mathrm{T}$ and Visser $\mathrm{C}$ "Confidential Information and the Danger of Confusing Classifications" 1993 SA Merc LJ 330-345

Posey and Dutfield Beyond Intellectual Property

Posey D and Dutfield G Beyond Intellectual Property (International Development Research Centre Ottawa 1996)

UNCTAD-ICTSD Resource Book on TRIPS

UNCTAD-ICTSD Resource Book on TRIPS and Development (Cambridge University Press Cambridge 2005)

Van Overwalle "Protection of Traditional Knowledge"

Van Overwalle G "Protection of Traditional Knowledge: a Critical Synthesis" in Grosheide W and Brinkhoj J (eds) Intellectual Property Law Articles on Cultural Expressions and Indigenous Knowledge (Intersentia Antwerp 2002) 251-266

Webster and Morley South African Law of Trade Marks

Webster CE and Morley GE Webster and Page South African Law of Trade Marks $4^{\text {th }}$ ed (LexisNexis Durban 2007)

WIPO Intellectual Property Needs

WIPO Intellectual Property Needs and Expectations of Traditional Knowledge Holders (WIPO Geneva 2001)

WIPO Model Provisions on Protection Against Unfair Competition

WIPO Model Provisions on Protection Against Unfair Competition (WIPO Geneva 1996)

Wynberg 2004 JWIP

Wynberg $R$ "Rhetoric, Realism and Benefit-sharing - Use of Traditional Knowledge of Hoodia Species in the Development of an Appetite Suppressant" 2004 JWIP 851-876 


\section{Register of court cases}

Atlas Organic Fertilizers (Pty) Ltd v Pikkewyn Ghwano (Pty) Ltd \& Others 19812 SA $173(\mathrm{~T})$

Canon KwaZulu-Natal (Pty) Ltd t/a Canon Office Automation v Booth and Another 20053 SA 205 (N)

Dun \& Bradstreet (Pty) Ltd v SA Merchants Combined Credit Bureau (Cape) (Pty) Ltd 19681 SA 209 (C)

Easyfind International (SA) (Pty) Ltd v Instaplan Holdings 19833 SA 917 (W)

Financial Mail (Pty) Ltd and Others $v$ Sage Holdings Ltd and Another 19932 SA 451 (A)

Harchris Heat Treatment (Pty) Ltd $v$ Iscor 19831 SA 548 (T)

Mathew $v$ Young 1922 AD 492

Patz v Greene \& Co 1907 TS 427

\section{Register of legislation}

Copyright Act 98 of 1978

Patents Act 57 of 1978

Trade Marks Act 194 of 1993

\section{Register of government publications}

Gen Not 552 in GG 31026 of 5 May 2008

\section{Register of international documents}

Agreement on Trade-Related Aspects of Intellectual Property Rights (TRIPS) (1994)

\section{Register of Internet sources}

Gervais 2001 www.cra-adc.ca

Gervais D 2001 Traditional Knowledge: A Challenge to the International Intellectual Property System www.cra-adc.ca/en/documents/traditionalknowledge\#contracts_trade_secrets [date of use 20 Apr 2009] 


\section{List of abbreviations}

\begin{tabular}{|c|c|}
\hline Afr J Trad CAM & $\begin{array}{l}\text { African Journal of Traditional, Complementary and } \\
\text { Alternative Medicines }\end{array}$ \\
\hline Case W Res J Int'I L & Case Western Reserve Journal of International Law \\
\hline IPQ & Intellectual Property Law Quarterly \\
\hline JWIP & Journal of World Intellectual Property \\
\hline SA Merc LJ & South African Mercantile Law Journal \\
\hline THRHR & Tydskrif vir Hedendaagse Romeins-Hollandse Reg \\
\hline TRIPS & $\begin{array}{l}\text { Agreement on Trade Related Aspects of Intellectual } \\
\text { Property Rights }\end{array}$ \\
\hline UNCTAD-ICTSD & Conference \\
\hline & $\begin{array}{l}\text { Development/International Centre on Trade } \\
\text { Sustainable Development }\end{array}$ \\
\hline WIPO & World Intellectual Property Organisation \\
\hline WTO & World Trade Organisation \\
\hline
\end{tabular}

